\title{
PENGARUH ARUS KAS OPERASI DAN LABA BERSIH TERHADAP HARGA SAHAM SYARIAH PADA PERUSAHAAN YANG TERDAFTAR DI JAKARTA ISLAMIC INDEX PERIODE 2017-2019
}

\author{
Nenden Ratna Ayu' ${ }^{1}$ \& Wirman ${ }^{2}$ \\ $1 \& 2$ Universitas Singaperbangsa Karawang \\ Email:1710631030132@student.unsika.ac.id,wirman@feb.unsika.ac.id
}

\begin{abstract}
ABSTRAK
Penelitian ini bertujuan untuk mengetahui pengaruh arus kas operasi dan laba bersih terhadap harga saham syariah pada perusahaan yang terdaftar di Jakarta Islamic Index periode 2017-2019. Jenis penelitian yang digunakan yaitu penelitian kuantitatif. Metode analisis yang digunakan pada penelitian ini yaitu analisis regresi linier berganda. Hasil penelitian secara parsial hanya laba bersih yang berpengaruh terhadap harga saham syariah sedangkan arus kas operasi tidak berpengaruh terhadap harga saham syariah pada perusahaan yang terdaftar di Jakarta Islamic Index (JII) periode 2017-2019. Secara simultan arus kas operasi dan laba bersih berpengaruh terhadap harga saham syariah pada perusahaan yang terdaftar di Jakarta Islamic Index (JII) periode 2017-2019.
\end{abstract}

Kata Kunci : Arus Kas Operasi, Laba Bersih, Harga Saham Syariah.

\begin{abstract}
This study aims to determine the effect of operating cash flow and net income on Islamic stock prices in companies listed on the Jakarta Islamic Index for the 2017-2019 period. The type of research used is quantitative research. The analytical method used in this study is Multiple Linear Regression Analysis. The results of the study are only partially net income that affects the price of Islamic shares, while operating cash flow has no effect on Islamic stock prices in companies listed on the Jakarta Islamic Index (JII) for the 2017-2019 period. Simultaneously, operating cash flow and net income have an effect on Islamic stock prices in companies listed on the Jakarta Islamic Index (JII) for the 2017-2019 period.
\end{abstract}

Keywords : Operating Cash Flow, Net Profit, Sharia Share Price. 


\section{PENDAHULUAN}

Kegiatan ekonomi yang diharapkan dapat memberikan profit pada jangka waktu tertentu merupakan pengertian dari investasi. Melalui investasi diharapkan harta yang dimiliki saat ini akan bermanfaat dan tidak akan habis secara sia-sia, melainkan dapat diolah seoptimal mungkin. Dengan demikian harta yang dimiliki dapat memenuhi berbagai macam bentuk kebutuhan, baik pribadi maupun kebutuhan keluarga, bahkan bisa menolong banyak orang dari manfaat harta yang dimiliki. Dalam konsep ajaran Islam investasi tidak hanya mendatangkan keuntungan yang bersifat duniawi saja, tetapi juga keuntungan yang bersifat akhirat, seperti pahala dan ridha Allah SWT yang akan didapat jika membangun fasilitas ibadah, sekolah, kesehatan dan lain sebagainya yang bersifat sosial dari hasil investasi yang dilakukan karena berkaitan dengan keimanan pada konsep ajaran Islam. Menanamkan hartanya di pasar modal merupakan salah satu konsep investasi dalam kegiatan ekonomi.

Pasar modal di Indonesia mempunyai peran yang sangat penting menjadi penggerak perekonomian nasional yang berfungsi untuk penyedia fasilitas dalam memberikan kemudahan perusahaan maupun emiten memperoleh dana juga untuk investor agar dapat mengalirkan dana yang dimiliki dengan harapan mendapatkan return atas dana yang telah disalurkannya. Prinsip-prinsip syariah Islam mulai diterapkan pada industri pasar modal di Indonesia sebagai alternatif instrumen kegiatan investasi di Indonesia. Diterbitkannya Jakarta Islamic Index (JII) pada tanggal 3 Juli 2000 menjadi awal perkembangan saham syariah di pasar modal Indonesia. Jakarta Islamic Index (JII) merupakan sekelompok saham perusahaan go public yang terdaftar di BEI dan telah memenuhi kriteria syariah Islam, di BEI tercatat 30 saham syariah yang likuid yang menjadi bagian dari JII. Pada tanggal 12 Mei 2011, BEI menerbitkan Indeks Saham Syariah Indonesia (ISSI) yang merupakan indeks komposit saham syariah yang tercatat di BEI. ISSI merupakan indikator untuk kinerja pasar saham syariah yang terdapat di Indonesia. Konstituen ISSI yaitu seluruh saham syariah yang tercatat di BEI dan masuk ke dalam Daftar Efek Syariah (DES) yang diterbitkan oleh otoritas jasa keuangan (OJK). Seleksi saham syariah yang masuk ke dalam ISSI tidak dilakukan oleh BEI.

Animo masyarakat terhadap produk yang menerapkan prinsip-prinsip syariah meningkat secara signifikan terlihat dari perkembangan bank-bank syariah, asuransi syariah yang berkembang pesat saat ini. Masyarakat Indonesia sebagian besar mayoritas beragama Islam membuat pertumbuhan pasar modal berbasis syariah meningkat dilihat pada jumlah investor saham syariah yang mengalami peningkatan selama empat tahun terakhir berdasarkan data Bursa Efek Indonesia (BEI) per Agustus 2020 investor saham syariah telah mencapai 78.199 investor atau sekitar 5,9 persen dari total investor saham Indonesia. Dalam berinvestasi para investor mengharapkan dana yang tersalurkan dalam pasar modal tersebut akan mendapatkan imbalan (return) yang mendatangkan keuntungan, tetapi imbalan (return) bisa juga berupa kerugian jika angka tersebut negatif atau minus. Dalam pasar modal syariah juga terjadi persaingan bisnis yang mengharuskan perusahaan agar saling bersaing serta menaikan kinerja keuangan sehingga dapat menarik para investor agar menyalurkan dananya diperusahaan tersebut. 
Laporan keuangan dapat menjadi media dalam meninjau kinerja keuangan dari sebuah perusahaan, dalam laporan keuangan, laporan arus kas merupakan salah satu komponen yang dapat digunakan oleh investor sebagai salah satu faktor pertimbangan dalam pengambilan keputusan. Laporan arus kas dapat digunakan untuk mengukur kinerja suatu perusahaan, karena informasi mengenai arus kas merupakan dasar untuk mengevaluasi kemampuan perusahaan dalam menghasilkan kas dan setara kas serta memahami bagaimana perusahaan mengelola arus kas. Selain informasi mengenai laporan arus kas pada laporan keuangan juga terdapat informasi tentang laba bersih yang terletak dalam laporan laba rugi. Informasi laba bersih adalah bagian dari komponen laporan keuangan perusahaan yang memiliki tujuan untuk mengevaluasi kinerja manajemen serta membantu mengestimasi kemampuan laba yang representatif dalam jangka panjang. Bukan hanya kinerja keuangan, harga saham juga dapat dijadikan sebagai dasar pertimbangan investor dalam pengambilan keputusan untuk berinvestasi. Keputusan berupa apakah akan membeli saham ataupun menjual saham yang telah dimiliki berdasarkan keadaan atau kondisi harga saham saat itu.

Beberapa penelitian terdahulu seperti yang dilakukan oleh Umdiana \& Hapsari (2016) melakukan penelitian dengan judul Analisis pengaruh arus kas bersih dan laba terhadap saham syariah. Hasil penelitian ini menunjukkan bahwa laba memiliki pengaruh positif terhadap harga saham Syariah.

Miranti, Marwoto dan Medinal (2017) melakukan penelitian dengan judul Pengaruh Laba Bersih dan Arus Kas Terhadap Harga Saham Pada Perusahaan Sektor Perbankan yang terdaftar pada Indeks LQ 45 Bursa Efek Indonesia Periode 2011-2015. Hasil penelitian menunjukkan Arus Kas dari Aktivitas Operasi berpengaruh positif terhadap harga saham .

Menurut Ridha (2019) yang melakukan penelitian dengan judul Pengaruh rasio keuangan, ukuran perusahaan, dan arus kas operasi terhadap harga saham syariah. Hasil penelitian ini menunjukkan bahwa Return on Equity (ROE), Total asset turnover (TATO), dan ukuran perusahaan berpengaruh positif terhadap harga saham perusahaan yang terdaftar di Indeks Saham Syariah Indonesia (ISSI). Sedangkan rasio NPM, rasio CR, rasio DER, dan arus kas operasi tidak berpengaruh terhadap harga saham.

Menurut Mas'ut dan Sijabat (2017) dalam penelitian Pengaruh Informasi Laba, total arus kas dan komponen arus kas terhadap harga saham pada perusahaan dagang yang terdaftar di Bursa Efek Indonesia. Penelitian ini menunjukkan Laba tidak berpengaruh secara parsial terhadap harga saham.

\section{TINJAUAN PUSTAKA}

\section{Teori Sinyal (Signalling Theory)}

Investor membutuhkan informasi tentang keadaan perusahaan, para pelaku bisnis harus memberikan informasi ini. Informasi ini berisi keterangan, catatan atau gambaran tentang kondisi masa lalu, sekarang dan masa depan ini dia perusahaan. Investor di pasar modal membutuhkan informasi yang lengkap, akurat dan tepat waktu sebagai alat analisis dalam pengambilan keputusan investasi (Gunawan, 2011).

Dalam teori ini, menyarankan bahwa perusahaan seharusnya memberikan sinyal kepada pengguna laporan keuangan. Bentuk sinyal ini adalah informasi tentang kondisi 
perusahaan kepada pemilik atau pihak terkait lainnya (misalnya: investor). Sinyal yang diberikan dengan mengungkapkan informasi akuntansi (misalnya laporan keuangan, laporan aktivitas yang telah dilakukan manajemen) Untuk memenuhi keinginan pemilik, atau bahkan untuk menunjukkan bahwa perusahaan tersebut lebih baik dari perusahaan lain dalam bentuk promosi dan informasi lainnya. Dengan informasi ini diharapkan dapat mempengaruhi pengambilan keputusan investor untuk berinvestasi. (Umdiana \& Hapsari, 2017)

\section{Harga Saham Syariah}

Menurut (Husnan, 2010) Saham syariah adalah saham dengan karakteristik yang sesuai dengan hukum syariah Islam. Saham tersebut membuktikan kepemilikan terhadap suatu perusahaan dalam bentuk perseroan terbatas (PT).

Menurut Jogiyanto (2016) Harga saham adalah harga dari suatu saham yang terdapat di bursa pada waktu tertentu yang ditentukan oleh pelaku pasar serta dikarenakan permintaan maupun penawaran saham yang bersangkutan di pasar modal.

\section{Arus kas operasi}

Arus kas operasi merupakan laporan mengenai pemasukkan dan pengeluaran kas yang disajikan secara ringkas (Hantono dan Rahmi, 2018).

Berdasarkan PSAK No. 2, "Arus kas operasi yaitu kegiatan penghasil pendapatan utama dari sebuah perusahaan, dan aktivitas yang lain selain dari aktivitas investasi dan aktivitas pendanaan".

\section{Laba Bersih}

Menurut Zamzami dan Nusa (2016) Selisih yang dihasilkan dari pendapatan dan biaya merupakan laba bersih, laba terjadi pada saat pendapatan lebih besar dibandingkan dengan pengeluaran atau biaya begitupun sebaliknya rugi terjadi pada saat pendapatan lebih sedikit atau kecil dibandingkan dengan pengeluaran atau biaya.

Menurut Hery (2015) Laba bersih yaitu laba atau rugi yang berasal dari operasi berlanjut ditambah maupun dikurangi oleh operasi yang dihentikan serta dikurangi dengan kerugian luar biasa memberikan pengguna laporan keuangan sebuah rangkuman dari kinerja perusahaan yang dilakukan dengan keseluruhan selama periode (baik yang bermula dari operasi berlanjut ataupun yang bukan).

\section{METODE PENELITIAN}

\section{Desain Penelitian}

Penelitian kuantitatif yaitu metode penelitian yang dipakai pada penelitian ini. Metode kuantitatif yaitu suatu metode yang menekankan analisisnya pada data-data numerikal atau angka yang diolah dengan menggunakan metode statistika (Suranto, 2019). Penelitian dengan metode kuantitatif ini dipakai dengan cara untuk menguji kebenaran dari suatu hipotesis yang dilakukan melalui pengaruh arus kas aktivitas operasi dan laba bersih terhadap harga saham syariah pada perusahaan yang terdaftar di Jakarta Islamic Index (JII) periode 2017-2019.

\section{Populasi dan Sampel}

Populasi merupakan wilayah generalisasi yang terdiri dari objek atau subjek dengan kualitas dan karakteristik tertentu, objek tersebut ditentukan dan disimpulkan oleh peneliti tertentu. Oleh karena itu, populasinya tidak hanya manusia, tetapi juga benda dan benda alam lainnya. Populasi bukan hanya jumlah objek atau subjek yang dipelajari, 
tetapi juga semua karakteristik objek atau subjek tersebut (Sugiyono, 2017).

Populasi yang digunakan dalam penelitian ini yaitu perusahaan yang terdaftar di Jakarta Islamic Index (JII) periode 2017-2019 sehingga diperoleh jumlah populasi sebanyak 30 perusahaan.

Sampel yaitu suatu bagian dari populasi. Hal ini mencakup sejumlah anggota yang dipilih dari populasi. Oleh karena itu, sebagian elemen dari populasi adalah sampel. Dengan mengambil sampel peneliti akan menarik kesimpulan yang digeneralisasi terhadap populasi (Hermawan, 2017). Purposive sampling digunakan untuk pengambilan sampel. Penulis memilih teknik purposive sampling dengan berbagai kriteriakriteria tertentu yang harus terpenuhi oleh sampel. Jumlah sampel yang memenuhi kriteria yang telah dipilih sebanyak 8 perusahaan.

Tabel 1. Sampel Penelitian

\begin{tabular}{llll}
\hline \multicolumn{4}{c}{ Daftar Perusahaan Yang Menjadi Sampel Penelitian } \\
\hline 1. & PT AKR Corporindo Tbk & 5. & PT Semen Indonesia Tbk \\
\hline 2. & PT Indofood CBP Sukses Makmur Tbk & 6. & PT Telkom Indonesia Tbk \\
\hline 3. & PT Kalbe Farma Tbk & 7. & PT Aneka Tambang Tbk \\
\hline 4. & Matahari Department Store & 8. & Unilever Indonesia \\
\hline & & Sumber : $w w w . i d x . c o . i d$
\end{tabular}

\section{HASIL DAN PEMBAHASAN}

\section{Uji Normalitas}

Uji normalitas berguna untuk menguji apakah dalam model regresi variabel independen dan variabel dependen berdistribusi normal atau mendekati normal.
Adapun Cara agar dapat mendeteksi apakah residual berdistribusi normal atau tidak adalah menggunakan analisis grafik (Normal P-P Plot) dan analisis statistik (One Sample Kolmogorov Smirnov), dengan hasil analisis sebagai berikut: 
Tabel 2. Hasil Uji Normalitas

One-Sample Kolmogorov-Smirnov Test

\begin{tabular}{llr}
\hline & & \multicolumn{2}{c}{$\begin{array}{c}\text { Unstandardized } \\
\text { Residual }\end{array}$} \\
\hline $\mathrm{N}$ & & 24 \\
\hline Normal Parameters & & .0000000 \\
\hline Most Extreme Differences & Mean & 7598.29089412 \\
\cline { 2 - 3 } & Std. Deviation & .126 \\
\cline { 2 - 3 } & Absolute & .126 \\
\cline { 2 - 3 } & Positive & -.090 \\
\hline Test Statistic & Negative & .126 \\
\hline Asymp. Sig. (2-tailed) & & $.200^{\mathrm{c}, \mathrm{d}}$ \\
\hline
\end{tabular}

Sumber : Data Olahan (2021)

Berdasarkan tabel 2 menunjukkan bebas (prediktor). Untuk mendeteksi ada bahwa nilai pada Asymp. Sig. (2-tailed) sebesar 0,200 artinya nilai tersebut lebih besar dari 0,05 maka asumsi normalitas terpenuhi.

\section{Uji Multikolinearitas}

Uji multikolonieritas bertujuan untuk menguji apakah model regresi ditemukan adanya korelasi antar variabel atau tidaknya multikolonieritas di dalam model regresi dapat dilihat dari (1) nilai toleransi dan lawannya (2) variance inflation factor (VIF). Jika nilai tolerance $>0,1$ dan VIF < 10, maka dapat diartikan bahwa tidak terdapat multikolinearitas pada penelitian tersebut. Hasil uji multikolinearitas dapat dilihat dari tabel berikut:

Tabel 3. Hasil Uji Multikolinieritas

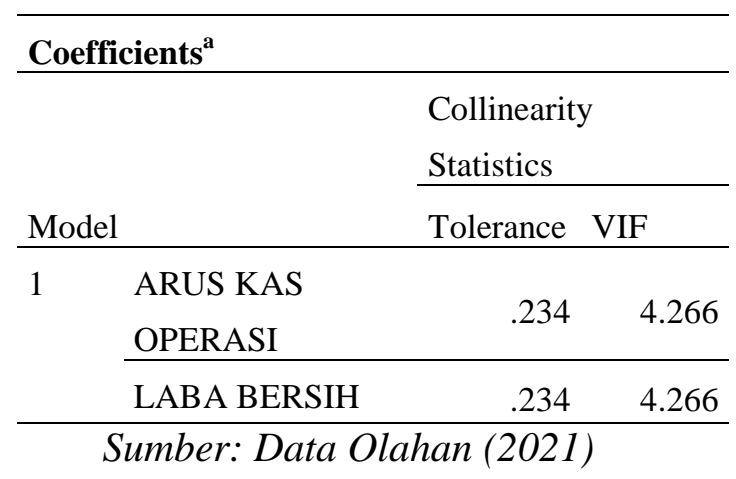

Berdasarkan tabel 3 menunjukkan bahwa seluruh variabel independen mempunyai nilai tolerance 0,234 lebih besar dari 0,1 dan nilai VIF 4,266 lebih kecil dari 10. Sehingga pada model regresi tidak terdapat masalah multikolinieritas.

\section{Uji Autokorelasi}

Uji autokorelasi bertujuan untuk menguji apakah dalam suatu model regresi linear ada korelasi antara kesalahan pengganggu pada periode $\mathrm{t}-1$ (sebelumnya). Jika terjadi korelasi, berarti terdapat auto correlation. 
Tabel 4. Hasil Uji Autokorelasi

\begin{tabular}{lr}
\hline Runs Test & \\
\hline & \multicolumn{2}{c}{$\begin{array}{l}\text { Unstandardized } \\
\text { Residual }\end{array}$} \\
\hline Test Value $^{\mathrm{a}}$ & 659.62542 \\
\hline Cases $<$ Test Value & 12 \\
\hline Cases >= Test Value & 12 \\
\hline Total Cases & 24 \\
\hline Number of Runs & 11 \\
\hline Z & -.626 \\
\hline Asymp. Sig. (2-tailed) & .531 \\
\hline \multicolumn{2}{c}{ Sumber : Data Olahan (2021) }
\end{tabular}

Berdasarkan tabel 4 dapat diketahui bahwa nilai Run Test sebesar 0,531 lebih besar dari 0,05 maka tidak terjadi autokorelasi.

\section{Analisis Regresi Linier Berganda}

Analisis regresi linear beganda digunakan peneliti dengan maksud untuk mengetahui dan membuktikan sejauh mana pengaruh arus kas operasi dan laba bersih terhadap harga saham syariah.

Tabel 5. Hasil Analisis Regresi Linier Berganda

\begin{tabular}{|c|c|c|c|c|c|c|}
\hline \multicolumn{7}{|c|}{ Coefficients $^{\mathrm{a}}$} \\
\hline \multirow[b]{3}{*}{ Model } & & \multirow{2}{*}{\multicolumn{2}{|c|}{ Unstandardized Coefficients }} & \multirow{2}{*}{$\begin{array}{l}\text { Standardized } \\
\text { Coefficients } \\
\end{array}$} & & \multirow[b]{3}{*}{ Sig. } \\
\hline & & & & & & \\
\hline & & $\mathrm{B}$ & Std. Error & Beta & $\mathrm{t}$ & \\
\hline \multirow[t]{3}{*}{1} & (Constant) & -4369.412 & 2927.900 & & -1.492 & .150 \\
\hline & ARUS KAS OPERASI & $-9.852 \mathrm{E}-7$ & .000 & -.163 & -.717 & .481 \\
\hline & LABA BERSIH & $6.546 \mathrm{E}-6$ & .000 & 1.003 & 4.410 & .000 \\
\hline
\end{tabular}

Berdasarkan hasil tabel 5, maka persamaan regresi linier yaitu :

$Y=-4369,412-9.9,852+6,546+e$

Keterangan :

1. Konstanta sejumlah $-4369,412$ berarti jika nilai pada variabel X1 (arus kas operasi) tidak meningkat dan X2 (laba bersih) menurun sehingga nilai variabel harga saham syariah menurun 4369,412 .
2. Koefisien regresi variabel $\mathrm{X} 1$ ( arus kas operasi) sebesar -9.9,852 menyatakan bahwa setiap penurunan pada arus kas operasi maka harga saham syariah akan menurun sebesar $-9.9,852$.

3. Koefisien regresi variabel X2 (laba bersih) senilai 6,546 artinya bahwa setiap laba bersih mengalami kenaikkan berakibat harga saham syariah akan meningkat senilai 6,546. 
Tabel 6. Hasil Uji F (Simultan)

\begin{tabular}{|c|c|c|c|c|c|c|c|c|}
\hline \multicolumn{9}{|c|}{ ANOVA $^{a}$} \\
\hline Model & & Sum of Squares & Df & & Mean Square & $\mathrm{F}$ & & Sig. \\
\hline \multirow[t]{3}{*}{1} & Regression & 3892355910.190 & & 2 & 1946177955.095 & & 30.778 & $.000^{\mathrm{b}}$ \\
\hline & Residual & 1327882563.768 & & 21 & 63232503.037 & & & \\
\hline & Total & 5220238473.958 & & 23 & & & & \\
\hline
\end{tabular}

Berdasarkan hasil uji F pada tabel harga saham syariah. Sehingga kedua 6 menampilkan nilai Sig. 0,000 berarti variabel independen disimpulkan bahwa nilai tersebut lebih kecil dari 0,05. terdapat pengaruh arus kas operasi dan Berdasarkan hasil itu berarti arus kas laba bersih terhadap harga saham syariah. operasi dan laba bersih berpengaruh pada

Tabel 7. Uji T (Parsial) Coefficients

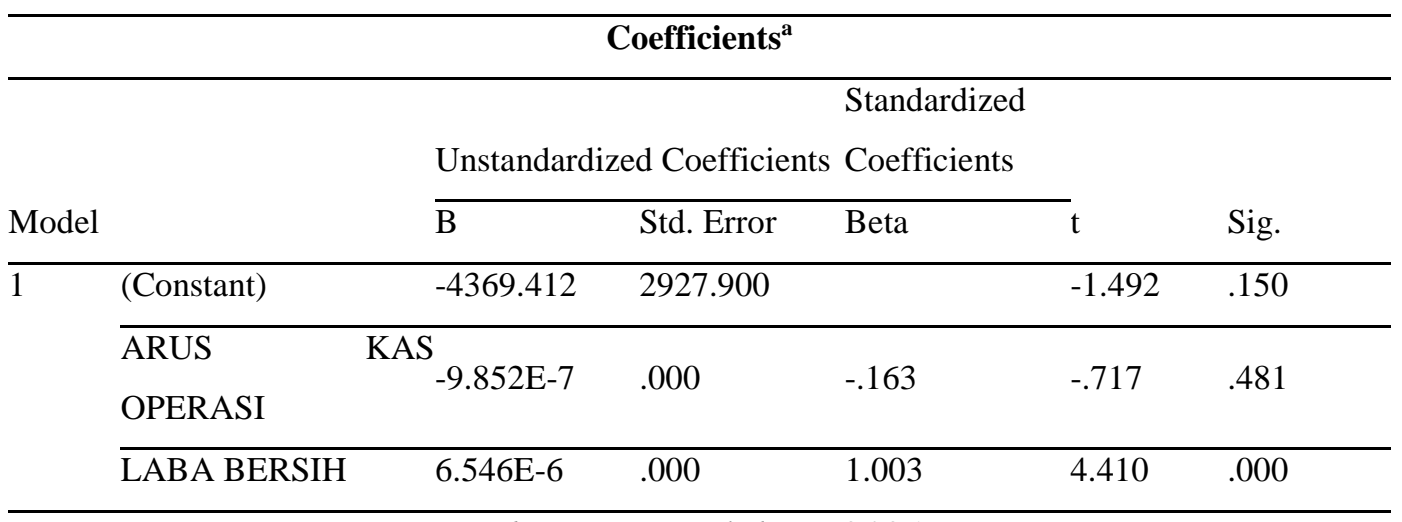

Sumber : Data Olahan (2021)

\section{A. Pengaruh Arus Kas Operasi B. Pengaruh Laba Bersih terhadap terhadap Harga Saham Syariah. \\ Harga Saham Syariah.}

Arus kas operasi diperkirakan mempunyai pengaruh pada harga saham syariah perusahaan yang terdaftar di Jakarta Islamic Index 2017-2019 berdasarkan tabel 6 menampilkan nilai tingkat signifikansi sebesar $5 \%$ dari tstatistik arus kas operasi sebesar 0,481, berarti nilai tersebut lebih besar dari 0,05. Harga saham syariah pada perusahaan yang terdaftar di Jakarta Islamic Index periode 2017-2019 tidak terpengaruh yang signifikan oleh arus kas operasi.

Laba bersih diduga memiliki pengaruh pada harga saham syariah perusahaan yang terdaftar di Jakarta Islamic Index 2017-2019 berdasarkan tabel 6 menunjukkan nilai tingkat signifikansi sebesar 5\% dari t-statistik laba bersih senilai 0,000 , berarti nilai itu lebih kecil dari 0,05. Sehingga, laba bersih berpengaruh signifikan terhadap harga saham syariah pada perusahaan yang terdaftar di Jakarta Islamic Index 20172019. 
Tabel 8. Koefisien Determinan (R Square)

\begin{tabular}{|c|c|c|c|c|}
\hline \multicolumn{5}{|c|}{ Model Summary $^{\mathbf{b}}$} \\
\hline Mod & & $\mathrm{R}$ & Adjusted & $\begin{array}{l}\text { Std. Error } \\
\text { of the }\end{array}$ \\
\hline el & $\mathrm{R}$ & Square & R Square & Estimate \\
\hline 1 & $.714^{\mathrm{a}}$ & .510 & .488 & 10782.504 \\
\hline
\end{tabular}

Pada tabel 8 menunjukkan nilai koefisien determinasi (R2) arus kas operasi serta laba bersih senilai 0,510 sehingga $0,510 \times 100 \%=51 \%$. Dapat ditarik kesimpulan bahwa arus kas operasi dan laba bersih berpengaruh sebesar $51 \%$ pada harga saham syariah. Adapun sisanya sebesar $49 \%$ dikarenakan oleh variabel lain selain dari variabel dalam penelitian ini.

\section{KESIMPULAN}

Penelitian ini bertujuan untuk mengetahui pengaruh arus kas operasi dan laba bersih terhadap harga saham syariah pada perusahaan yang terdaftar di Jakarta Islamic Index periode 2017-2019. Berdasarkan hasil yang diperoleh dari penelitian ini secara parsial hanya laba bersih yang berpengaruh terhadap harga saham syariah sedangkan arus kas operasi tidak berpengaruh terhadap harga saham syariah pada perusahaan yang terdaftar di Jakarta Islamic Index (JII) periode 20172019. Sedangkan secara simultan arus kas operasi dan laba bersih berpengaruh terhadap harga saham syariah pada perusahaan yang terdaftar di Jakarta Islamic Index (JII) periode 2017-2019.

\section{DAFTAR PUSTAKA}

Gunawan. 2011. Pengaruh Analisis Fundamental Terhadap Harga Saham (Studi Kasus Terhadap Saham-saham Syaria'ah di Jakarta Islamic Indeks). Jurnal Wira Ekonomi Mikroskil: JWEM, 1(1), p. 47-58.
Hantono dan Rahmi, Namira Ufrida R. 2018. Pengantar Akuntansi. Deepublish.Yogyakarta.

Hermawan, A. d. 2017. Penelitian Bisnis Pendekatan Kuantitatif. Kencana. Jakarta.

Hery. 2015. Pengantar Akuntansi Comprehensive Edition. Grasindo. Jakarta.

Husnan, Suad. (2010). Dasar-Dasar Teori Portifolio Dan Analisis Sekuritas. UPP YKPN. Yogyakarta.

Jogiyanto, H. (2016). Teori Portofolio dan Analisis Investasi Edisi Kesepuluh. BPFE-Yogyakarta.

Mas'ut \& Sijabat, Nurhasanah. 2017. Pengaruh Informasi Laba, Total Arus Kas Dan Komponen Arus Kas Terhadap Harga Saham Pada Perusahaan Dagang Yang Terdaftar Di Bursa Efek Indonesia. JRAM (Jurnal Riset Akuntansi Multiparadigma), 4(3), p. 42-48.

Miranti., Marwoto, Pan Budi., \& Medinal. 2017. Pengaruh Laba Bersih Dan Arus Kas Terhadap Harga Saham Pada Perusahaan Sektor Perbankan Yang Terdaftar Pada Indeks LQ 45 Bursa Efek Indonesia Periode 2011-2015 (Studi Kasus Pada PT Bursa Efek Indonesia). Jurnal Akuntansi Bisnis \& Keuangan (JIABK), 9(2), p. 31-43. 
Ridha, M. Arsyadi. 2019. Pengaruh Rasio Keuangan, Ukuran Perusahaan, dan Arus Kas Operasi terhadap Harga Saham Syariah. JIA (Jurnal Ilmiah Akuntansi), 4(2), p. 184200.

Sugiyono. 2017. Metode Penelitian Kuantitatif, Kualitatif,dan $R \& D$. Alfabeta. Bandung.

Suranto. 2019. Metodologi Penelitian dalam Pendidikan dengan Program SPSS. Loka Aksara. Tangerang.

Umdiana, Nana., \& Hapsari, Denny Putri. 2016. Analisis Pengaruh Arus Kas Bersih Dan Laba Terhadap Saham Syariah. JAK (Jurnal Akuntansi) Kajian Ilmiah Akuntansi, 3(1), p. 16-23.

Umdiana, Nana., \& Hapsari, Denny Putri. 2017. Menguji Struktur Modal Sebagai Variable Intervening Dalam Pengaruh Arus Kas Terhadap Harga Saham Syariah. JAK (Jurnal Akuntansi) Kajian Ilmiah Akuntansi, 4(2), p. 48-58.

Zamzami, Faiz., \& Nusa, Nabella Duta. 2016. Akuntansi Pengantar 1. Gadjah Mada University Press. Yogyakarta. 